\title{
The Impact of High Involvement Management on Employee Retention
}

\author{
Hassan Ismail \\ Researcher, Department of Human Resource Management, Higher Institute of Business \\ Administration, Damascus, Syria \\ E-mail: Hassanisml@gmail.com

\begin{abstract}
Ahmad Warrak (Corresponding Author)
Researcher, Department of Human Resource Management, Higher Institute of Business Administration, Damascus, Syria

E-mail: Ahmad.warrak@gmail.com
\end{abstract}

Received: Dec. 15, 2019 Accepted: Jan. 10, 2020 Online published: Jan. 17, 2020

doi:10.5296/ijhrs.v10i1.16261

URL: https://doi.org/10.5296/ijhrs.v10i1.16261

\begin{abstract}
The purpose of this study is to explore the impact of high involvement management (power, information, rewards, and knowledge) on employee retention in Syrian Private Financial Institutions. A sample of 238 employees participated in this study. The research concluded that there is a significant positive impact of rewards and knowledge practices on employee's retention, without any significant impact from power and information practices on employee's retention.
\end{abstract}

Keywords: high involvement management, power, information, rewards, knowledge, and employee retention

\section{Introduction}

With the increasing acknowledgement that people are an organization's best asset (Guy, 2003; Rodgers \& Ferketish, 2005), there is a desire to find ways to increase employee's contribution to the organization while better understanding how effective human resource systems operate. If an organization can recruit and retain the right employees, and develop them through training and skill acquisition, this knowledge can be used as a competitive advantage to drive the organization forward (Guy, 2003). The difficulty is how best to develop a system that will allow for this type of symbiotic relationship between employee and organization. High 
involvement management (HIM) permits for more input from employees and allow organizations to optimize their innate abilities more efficiently and effectively (Rodgers \& Ferketish, 2005). Through employee participation, organizations should be able to develop a better insight into how they are functioning, and potentially, where improvements could be made to benefit both the organization and the employees (Guy, 2003). If HIM increase organizational performance and decreases employee turnover, it can provide both financial benefits and organizational stability. Decreased turnover allows an organization to retain collective knowledge that may be lost by the organization to competitors. Moreover, it also decreases the amount of finance required for recruitment and training while providing an attractive culture to potential employees who wish to have job security (Rodgers \& Ferketish, 2005; Way, 2002).

This study aims to examine the impact of high involvement management (Power, Information, Rewards, and Knowledge), on employee retention in Syrian Private Financial Institutions. The result of this study may help decision makers in a Syrian organization to understand what helps in retaining employees which in turn can help the organizations in achieving high levels of organizational performance.

\section{Literature Review and Hypothesis Development}

\section{High involvement management:}

High involvement management is thought to optimize organizational performance by way of a twofold process. First, it helps employees acquire and develop knowledge, skills, and abilities (KSA) (i.e., human capital) along with empowering them (by way of motivation and providing opportunity) to use KSA towards achieving organizational objectives (Becker \& Huselid, 1998). Second, by reducing departmental barriers, these HR systems also contribute to creating a culture and social structure that is conducive to communication, knowledge sharing, and resource exchange (Evans \& Davis, 2005). Thus, unlike the traditional control-oriented approach that views employees more as a replaceable commodity, organizations employing High Involvement Management is more employee-centered by design in that organizations invest a lot in their employees (Guthrie, 2001). Employees in these organizations represent an embodiment of human as well as social capital. Consequently, these organizations rely much more on their "invisible assets" (Itami, 1987) compared to their counterparts utilizing a traditional approach to managing human resources (Guthrie, 2001; Lawler, 1992).

Building on the work of Galbraith (1973), Lawler (1986; 1992) defined the components of High involvements management as PIRKs:

- Power to make or influence work decisions in all aspects.

- Information about processes, quality, customer feedback, events and business results.

- Rewards tied to business results and personal growth in terms of capability and contribution.

- Knowledge of the work, the business and the total work system. 
The most important aspect of Lawler's premises is the need for all of the PIRK components to be utilized simultaneously down to the lowest levels of the organization. This is articulated in the following quote from Lawler (1986):

"Power without knowledge, information and rewards is likely to lead to poor decisions; Information and knowledge without power leads to frustration because people cannot use their expertise. Rewards for organizational performance without power, knowledge and information can lead to frustration and lack of motivation because people cannot influence their rewards; and Information, knowledge and power without rewards for organizational performance are dangerous because nothing will ensure that people will exercise their power in ways that will contribute to organizational effectiveness".

Lawler's statement implies that the existence of PIRK at all levels of the organization demonstrates that there is a climate or a culture for High Involvement Management. This also implies that this culture results in certain positive outcomes for the organization (productivity, reduced turnover, speed).

\section{Employee Retention}

Many reasons make people leave an organization, such as, job related stress, lack of job security and personal dissatisfaction. (Mckeown, 2002) explained his view on employee retention, which focuses primarily on retaining better-performing people rather than those with lower performance. He considered that there is no precise definition of employee retention because people's perception of retention varies. However (Mckeown, 2002), he found that some managers explained that employee retention is "a reduction in the turnover of work to an acceptable level while others believe that retention is related to compensation and benefits that workers receive, moreover, some believe that it is related to culture, that is, how The worker is treated within the organization. "

Arthur (2001) also indicated that retention is only for younger workers, as organizations must be open to offer alternatives to them and to find exciting or entertaining opportunities that expand their knowledge, skills, and interests. Meanwhile (Browell, 2003) stated that the definition of employee retention is "to keep those workers who wish to keep them and not lose them from the organization for any reason, especially if they are transferred to competing organizations". He also clarified that the essential workers who occupy positions sensitive to the success of the organization must be retained at any cost.

According to Kavitha et al., 2011, employee retention has become one of the most pressing issues facing organizations and human resource managers in recent times. As workers who increasingly leave the organization create a weak loyalty index for this organization. They also stated that the successful organization is the one that seeks to reduce the depletion of the company's profits, so it is better to reduce the turnover of its employees. Moreover, they (Ratna et Chawla, 2012) considered that employee retention is more important than employment, although hiring people with knowledge is essential for organizations. Keeping workers also refers to taking appropriate measures to encourage people to stay in the organization as long as they can, and considered that "the process of retaining employees will benefit the organization, since the cost of employee turnover is losing hundreds of thousands 
of money to the organization's account." (Mohlala et al., 2012) pointed out these different factors that affect the retention of workers after reviewing some previous studies, especially in the information technology industry, these factors include: lack of determination of the desired salary, lack of development of the professional path for workers, technology development and high rate Employee turnover. They suggested that it is best for organizations to consider these factors as a basis for defining the concept of employee retention.

\section{High involvement management and employee retention}

Previous studies (e.g. Huselid, 1995; Shaw, Delery, Jenkins, \& Gupta, 1998; Vandenberg, Richardson, \& Eastman, 1999) have also shown that high-involvement management enhance employee retention. Support theory holds that beneficial actions directed at employees should obligate employees to reciprocate in a positive manner. HR practices represent such organizational actions that may reinforce the employees' beliefs that the organization values their contributions and cares about their well-being, which in turn reduces turnover intentions among employees (Eisenbeger et al., 1990; Wayne et al., 1997)

(Mondore, 2002) studied the high involvement management through three dimensions (empowerment, incentives, information sharing) and its effect on intention to leave work, job satisfaction, organizational commitment, self-efficacy, absenteeism rates, organizational citizenship behavior, Performance, this study was applied to workers in financial institutions in the United States of America, where the study concluded that the high involvement management affects the intention to leave work without any intermediate variables.

(Pare and other, 2004) tried to find out the role of high involvement management in intention to leave work for informatics workers in Canada, and the mediating role of organizational commitment, organizational citizenship behavior, and procedural justice. Where the high involvement management included a set of dimensions which are (estimation, empowerment, competency development, fairness of incentives, information sharing). The study reached two basic models:

- The first model: Emotional commitment mediates the relationship between three of the five dimensions of the high involvement management (appreciation, empowerment, competency development) and intent to quit work, while continuity commitment mediates after developing competencies and intent to quit work.

- The second model: mediation of procedural justice, followed by organizational citizenship behavior, the relationship between four of the five dimensions of high involvement management (appreciation, competency development, incentive justice, information sharing) and intent to quit work.

As for (Doody, 2007) considered that organizations can create a competitive advantage through the ways in which the human resource management strategy is designed, the researcher studied the high involvement management and its impact on increasing organizational performance and reducing the turnover of workers in New Zealand organizations, as these included The strategy is a set of dimensions, which is (authority, 
estimation, information, knowledge), so the researcher concluded that there is no effect of high involvement management in organizational performance, and reducing employee turnover, due to the researcher's view that there is no clear role high involvement management in this relationship because of organizational performance within different organizations because of this lack of study on the application of a particular sector.

When (Conci and other, 2009) developed a measure of the high involvement management in Spanish organizations, where the study sample consisted of 48 managers, the researchers reached to define four basic dimensions of high involvement management which are participation, communications, training and compensation. Knowledge management.

The Quagraine, 2010 study, which was applied to workers in a bank in Ghana, confirmed that the participation of workers in decision-making is one of the dimensions of the high involvement management which is a fuel that runs the engine of the organization, and the study also concluded that there is a relationship Between the participation of workers in decision-making and the implementation of these decisions. The study also revealed that workers who do not participate in decision-making become detracted from the organization, which leads to the difficulty of retaining them.

As for (Wadhwa, 2012) he studied the role of high involvement management and supporting the supervisor of organizational effectiveness, which included peer support and work characteristics as an intermediate variable and work rotation as a dependent variable, the study included 248 managers in a number of organizations in the United States of America, and reached The researcher indicates that peer support and job characteristics are intermediate variables between a strategy of high career immersion / higher employee engagement and supervisor support, and work turnover.

(Vugt, 2015) studied the impact of the high involvement management in the frequent absence rates, which in turn leads to the organization's inability to retain workers and the mediating role of job satisfaction, as the study was applied to 97 workers in the healthcare sector in the Netherlands, and the study concluded that high involvement management affects the reduction in frequent absenteeism rates.

(Martin, 2016) examined the impact of strategic human resources management on the motives of workers on the one hand, and on their behavior in leaving work on the other hand, where the researcher adopted two strategies from human resources management strategies which are participation in the high involvement management, and the use of communications technology and information. This study was applied to workers in the field of communications and informatics in France, and accordingly, the application of the high involvement management contributes to reducing the intentions of leaving the work for the workers who are motivated by professional development, more than those who are motivated by reward and punishment.

Most studies conducted in the field of high involvement management confirmed the positive impact it has on innovation, employee retention, creativity, and the quality and quantity of work, but there are studies that have shown opposite results, so a study (Cappelli et al., 2001) 
showed that a high involvement management has led to higher labor costs, and these practices can lead to lower employee welfare due to the pressures they are exposed to and increased responsibilities, and ultimately the organization's performance and the worker's desire to leave his organization (Böckerman and Other, 2012).

\section{Hypothesis}

According to the literature review presented above, we hypothesize that:

H1: power has a positive impact on employee retention.

H2: information has a positive impact on employee retention.

H3: Rewards have a positive impact on employee retention.

H4: Knowledge has a positive impact on employee retention.

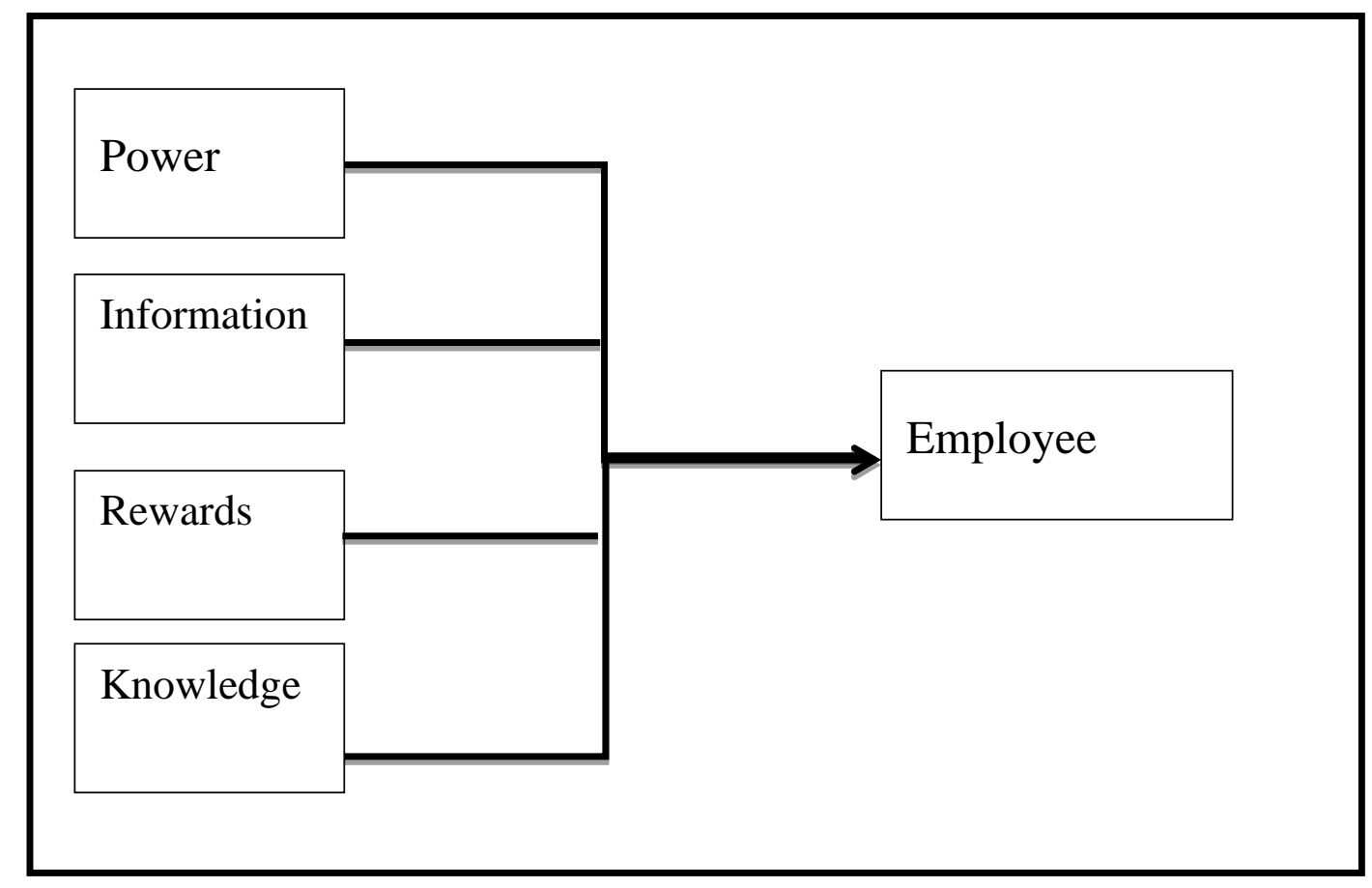

Figure 1. Research Model

Source: Author

\section{Research Methodology}

\section{Data Collection and Sample:}

Data for this study was collected from both primary and secondary sources. Secondary data was collected through comprehensive literature review. Primary data was collected from number of Syrian Private Financial Institutions located in Damascus. A total sample of 238 employees accepted to answer a questionnaire related to the study variables. 


\section{NI Macrothink}

\section{Measures}

The questionnaire includes three sections: Basic demographic information, High involvement management (power, information, rewards, knowledge), and Employee retention. A 5-Point Likert scale format was used, and the scores on the scale ranged from 1: Strongly Disagree to 5: Strongly Agree.

4.1. High involvement management scale: measured using 32 items taken from the study (Lawler et al., 1992). The scale reported reliability 0.949

4.2. Employee retention scale: measured using 11 items taken from the study (Kyndt et al., 2009). The scale reported reliability 0.864

\section{Finding}

This study examines the impact of high involvement management on employee retention.

Table (1) shows the results of regression analysis regarding the impact of high involvement management on the dependent variable (employee retention). As presented in this table, model is significant at the $5 \%$ level (where $\mathrm{R}^{2}$ is 0.427 ). Table (2) shows The Coefficient of Rewards are significant and positive on employee retention (Sig: $0.000<0.05$ ) with $\beta$ weight 0.451 and knowledge is significant and positive on employee retention (Sig: $0.002<0.05$ ) with $\beta$ weight 0.162 . Thus, $\mathrm{H} 3$ and $\mathrm{H} 4$ are accepted, while $\mathrm{H} 1$ and $\mathrm{H} 2$ are rejected, Because Information has no significant impact on employee retention (Sig: $0.504>0.05$ ) with $\beta$ weight 0.047 and Information has no significant and positive impact on employee retention (Sig: $0.093>0.05$ ) with $\beta$ weight -0.124 .

These findings indicate that when organization apply High involvement management (rewards and knowledge) they will be more likely to retain their employees.

Table (1). Model Summary

\begin{tabular}{|l|l|l|l|l|}
\hline Model & $\mathrm{R}$ & R Square & $\begin{array}{l}\text { Adjusted R } \\
\text { Square }\end{array}$ & $\begin{array}{l}\text { Std. Error of } \\
\text { the Estimate }\end{array}$ \\
\hline 1 & $.653^{\mathrm{a}}$ & .427 & .417 & .48827 \\
\hline
\end{tabular}

a. Predictors: (Constant), Power, Information, Rewards, Knowledge

Table (2). Coefficientsa

\begin{tabular}{|c|c|c|c|c|c|c|}
\hline \multirow{2}{*}{\multicolumn{2}{|c|}{ Model }} & \multicolumn{2}{|c|}{$\begin{array}{l}\text { Unstandardized } \\
\text { Coefficients }\end{array}$} & \multirow{2}{*}{$\begin{array}{c}\text { Standardized } \\
\text { Coefficients } \\
\text { Beta }\end{array}$} & \multirow[b]{2}{*}{ t } & \multirow[b]{2}{*}{ Sig. } \\
\hline & & B & Std. Error & & & \\
\hline \multirow[t]{5}{*}{1} & (Constant) & 1.582 & .253 & & 6.254 & .000 \\
\hline & Power & $-.124-$ & .074 & $-.101-$ & -1.686 & .093 \\
\hline & $\begin{array}{l}\text { Informatio } \\
n\end{array}$ & .047 & .070 & .047 & .669 & .504 \\
\hline & Rewards & .451 & .067 & .513 & 6.776 & .000 \\
\hline & $\begin{array}{l}\text { Knowledg } \\
\text { e }\end{array}$ & .162 & .053 & .212 & 3.074 & .002 \\
\hline
\end{tabular}

a. Dependent Variable: Employee Retention 


\section{Conclusion}

This article aimed to study the relationship between high involvement management and employee retention in Syrian Private Financial Institutions located in Damascus. This study show that rewards and knowledge are significant and have a positive impact on employee retention, while power and information did not show any significant impact on employee retention.

With HIM, employee rewards should also to be part of the decision. Employees need to be allowed to participate fully in aspects of the organization. This needs to include sharing information. Previous research (Lloyd, 2000) has shown clearly that people are motivated by different pay structures, and this needs to fit with the involvement, as motivation is one of the keys to HIWS success in the organization. This seems to be an area that Syrian organizations need to develop. Many organizations indicated that they had staff training and shared information with employees. However, it is difficult to gauge if the decisions made about training and the level of information shared with employees is based on reciprocity or did upper management make an isolated decision?

We recommended that organization should share all information related to its financial performance, especially that financial institutions are obligated towards government agencies to publish quarterly data on their performance at the end of each quarter and these data are published within the website of the Damascus Securities Exchange, Syrian Commission on Financial Markets and Securities, and official newspapers, and therefore there is no problem with publishing this information is on its employees

\section{Theoretical Implications}

This study has several theoretical implications, First This research is considered from the researchers' point of view, and after reviewing the sources of the research, one of the first studies that touched The impact of High Involvement Management on Employee Retention, and applying this research in Syrian Private Financial Institutions, the current study is an enrichment of the scientific and research aspect of the Syrian Private Financial Institutions, due to the role of these institutions in developing the financial sector in Syria, which is currently considered one of the most important sectors supporting in Syrian economy. Second, we have revealed the influence of High Involvement Management on Employee Retention. Moreover, our results provide evidence for notion that the survival and success of an organization depend on the ability of how to retain employees, in light of the great competition between organizations.

\section{Practical Implications}

Our findings also have several practical implications. First Assist human resource managers in reducing the turnover rates. Second they showed that employees' perceptions of High Involvement Management are of pivotal importance regarding their attitudes and behaviors. Namely, employees who consider that their organization implements such work practices experience lower levels of intention to leave, and high optional to retain them. such, contemporary human Resource management practices such as Rewards and Knowledge. 


\section{Mll Macrothink}

International Journal of Human Resource Studies ISSN 2162-3058 2020, Vol. 10, No. 1

Private financial institutions should pay attention to the intention to leave for employees and focus on retaining them by conducting a periodic survey of workers' opinions related to matters that may cause these intentions, including according to many previous studies, job satisfaction, work pressure, job combustion and organizational justice, with the aim of avoiding the intent of leaving the organization, and adopting the exit interview to find out the reasons that prompted the employees leave the organization, and work to improve this reasons that prompted the workers to leave their work.

\section{Suggestion for Future Research:}

This study shows that there is a direct relationship between High Involvement Management (Power, Information, Rewards, and Knowledge) and employee retention without examining the effects of organizational factors on this relationship such as the mediation role of leadership style. Therefore, we suggest that researchers examine how organizational variables can influence on High Involvement Management in relation to employee retention under these organizational factors.

\section{References}

Arthur, D. (2001). Employee recruitment and retention handbook. New York: American Management Association (AMACOM), $1^{\text {st }}$ edition.

Becker, B. E., \& Huselid, M. A., (1998). High performance work systems and firm performance: A synthesis of research and managerial implications. In G. R. Ferris (Ed.), Research in Personnel and Human Resource Management, 16: 53-101.

Böckerman, P., Johansson, E. \& Kauhanen, A., (2012). Innovative work practices and sickness absence: What does a nationally representative employee survey tell. Industrial and Corporate Change, 21(3), 587-613. https://doi.org/10.1093/icc/dtr047

Browell, S. (2003). Staff retention in a week. Great Britain: Hodder \& Stoughton.

Cappelli, P., \& Neumark, D. (2001). Do high-performance work practices improve establishment-level outcomes. Industrial and Labor Relations Review, 54(4). https://doi.org/10.2307/2696111

Conci, G., \& Marin-Garcia, J, (2009). Exploratory study of high involvement work practices: identification of the dimensions and proposal of questionnaire to measure the degree of use in the company. Intangible Capital, 5(3). https://doi.org/10.3926/ic.2009.v5n3.p278-300

Doody, S. (2007). High-involvement work systems: Their effect on employee turnover and organisational performance in New Zealand organisations, Lincoln University, New Zealand.

Eisenberger, R., Fasalo, P., \& Davis-LaMastro, V. (1990). Perceived organizational support and employee diligence, commitment and innovation. Journal of Applied Psychology, 75, 51-59. https://doi.org/10.1037/0021-9010.75.1.51 
Evans, W. R., \& Davis, W. D., (2005). High- performance work systems and organizational performance: The mediating role of internal social structure. Journal of Management, 31(5), 758-775. https://doi.org/10.1177/0149206305279370

Galbraith, J. R. (1973), Designing complex organizations. Reading, MA: Addison-Wesley.

Guthrie, J. P. (2001). High involvement work practices, turnover and productivity: evidence from New Zealand. Academy of Management Journal, 44, 180-190. https://doi.org/10.2307/3069345

Guy, F. (2003). High-involvement work practices and employee bargaining power. Employee Relations, 25(4/5). https://doi.org/10.1108/01425450310490165

Huselid, M. (1995). The impact of human resource management practices on turnover, productivity, and corporate financial performance, Academy of Management Journal, 38(3), 635-672. https://doi.org/10.2307/256741

Itami, H. (1987). Mobilizing invisible assets. Cambridge, MA: Harvard University Press.

Kavitha, S. R., Geetha, S. R., \& Arunachalam, V. (2011). An empirical study on employee retention strategies in a biscuit manufacturing company in India. Interdisciplinary Journal of Contemporary Research in Business, 3(4), 762-774.

Kyndt, E., Dochy, F., Michielsen, M., \& Moeyaert, B. (2009). Employee retention: organisational and personal perspectives, Vocations and Learning, 2(3), 195-215. https://doi.org/10.1007/s12186-009-9024-7

Lawler, E. E. (1986). High involvement management. San Francisco: Jossey-Bass.

Lawler, E. E. (1992). The ultimate advantage: Creating the high involvement organization. San Francisco: Jossey-Bass.

Lloyd, C. (2000). High involvement work systems: The only option for UK high skill sectors? SKOPE Research Paper, 11.

Martin, L. (2016). High involvement management practices, technology uses, work motivation and job search behavior, Luxembourg Institute of Socio-Economic Research. https://doi.org/10.2139/ssrn.2749570

Mckeown, L. J. (2002). Retaining top employees. New York: McGraw-Hill.

Mohlala, J., Goldman, G. A., \& Goosen, X. (2012). Employee retention within the information technology division of a South African Bank. South African Journal of Human Resource Management, 10(2), 1-11. https://doi.org/10.4102/sajhrm.v10i2.438

Mondore, S. (2002). Cognitive and motivational influences of high involvement work processes on employee morale, performance, and turnover. University of Georgia.

Pare, G., \& Tremblay, M., (2004), The influence of high-involvement human resources practices, procedural justice, organizational commitment and citizenship behaviors on information technology professionals' turnover intentions, HEC Montréal,0832-7203. 


\section{Macrothink}

International Journal of Human Resource Studies

ISSN 2162-3058 2020, Vol. 10, No. 1

Quagraine, T. L. (2010), Employee involvement as an effective management tool in decisionmaking: A case study of Merchant Bank (Ghana) Limited, Kwame Nkrumah University of Science and Technology.

Ratna, R., \& Chawla, S. (2012). Key factors of retention and retention strategies in telecom sector. Global Management Review, 6(3), 35-46.

Rodgers, R. W., \& Ferketish, B. J. (2005). Creating a high-Involvement culture through a value-driven change process. Development Dimensions International.

Shaw, J. D., Delery, J. E., Jenkins Jr., G. D., \& Gupta, N. (1998). An organizational-level analysis of voluntary and involuntary turnover. Academy of Management Journal, 41(5), 511-525. https://doi.org/10.2307/256939

Vandenberg, R. J., Richarson, H. A., \& Eastman, L. J. (1999). The impact of high-involvement work process on organizational effectiveness. Group \& Organization Management, 24(3), 300-339. https://doi.org/10.1177/1059601199243004

Vugt, V. (2015). The effect of high involvement work system and empowerment oriented leadership on job satisfaction and absence frequency, Tilburg University.

Wadhwa, P. (2012). The relationship between high involvement work system, supervisory support, and organizational effectiveness: The role of employee experiences at work. University of Kansas, USA.

Way, S. A. (2002). High performance work systems and intermediate indicators of firm performance within the US small business sector. Journal of Management, 28(6), 765-785. https://doi.org/10.1177/014920630202800604

Wayne, S. J., Shore, L. M., \& Linden, R. C. (1997). Perceived organizational support and leader member exchange: A social exchange perspective. Academy of Management Journal, 40(1), 82-111. https://doi.org/10.2307/257021

\section{Copyright Disclaimer}

Copyright for this article is retained by the author(s), with first publication rights granted to the journal.

This is an open-access article distributed under the terms and conditions of the Creative Commons Attribution license (http://creativecommons.org/licenses/by/4.0/). 